\title{
Evaluation of Efficacy of Walnut (Juglans Nigra) On Blood Pressure, Haematological and Biochemical Profile of Hypertensive Subjects.
}

\author{
${ }^{1}$ F. N Oguwike, ${ }^{2}$ S. Ebede, ${ }^{3}$ C. C Offor \\ ${ }^{I}$ Department of Human Physiology, Anambra Staten University Uli, Anambra State Nigeria. \\ ${ }^{2}$ Department of Medical Microbiology, University of Nigeria Teaching Hospital Ituku Ozalla Enugu Nigeria. \\ ${ }^{3}$ Department of Medical Biochemistry, Anambra State University Uli, Anambra State, Nigeria.
}

\begin{abstract}
The potential anti-hypertensive effects associated with the administration of walnut was investigated using 130 hypertensive subjects. Result showed that Juglans nigra normalizes high blood pressure if short term meal of walnut is taken; other parameters that walnut normalises are high cholesterol and serum electrolytes. Walnut meal has no effect on haemoglobin concentration, white blood cell count, Packed cell volume and platelet counts compared with their corresponding controls. It could be deduced from this study that walnut contains some principle elements that is anti-hypertensive.
\end{abstract}

Key Words: Walnuts, Hypertension, Haemoglobin, Cholesterol, Serum, Electrolytes.

\section{Introduction}

In most developing countries especially the sub- Saharan part of Africa, people mostly depend on herbal medical cure. In the eastern part of Nigeria among the Ibos, traditional medicine has been virtually used in preventing and curing diseases, thereby playing an important role in the health service in the region especially among the low social economic class. Those herbs are mostly administered orally through the GIT or can be applied topically as ointment. Extracts of fruits, roots, stem, bark and leaves of some medicinal plants have been known to have effect against the most dreaded pathogenic organisms.

Walnuts are rounded single seeded stone fruits of the walnut tree of the genus Juglans especially the Persian or English walnut, Juglans regia. That of the eastern black walnut is called Juglans nigra. They are highly density source of nutrients particularly proteins and essential fatty acids (commonly profile, 2006). The walnut fruit is enclosed in a green, leathery fleshy husk. This husk is inedible. The nutrient profile (Nutrient data, 2010) noted that it contains carbohydrate, proteins, fiber, calcium, iron zinc, vitamin B6 and Unsaturated fatty acids. The scourge of high blood pressure in young middle age and elderly people and the related diseases and sudden death that associates with it sometimes prompted my curiosity to search out for a lasting and simple remedy that will arrest this scourge, also alleviate the situation and subjects will not depend on chemotherapeutic treatments.

Blood pressure is the force with which the heart pumps blood through the blood vessels to various parts of the body. A higher pressure is generated when the lower chambers of the heart contract and squeeze the blood through the arteries. This pressure is known as systolic. When the heart relaxes a lower pressure is generated and this is called diastolic pressure. The blood pressure is written as systolic over diastolic i.e. SYSTOLIC $\mathrm{mmHg}$

\section{Diastolic}

When the blood pressure measured in millimeters of mercury $(\mathrm{mmHg})$ is above the normal range the person is said to have high blood pressure or hypertension (Akubue, 2000). The blood pressure may be below the normal range and the person is said to have low blood pressure or hypotension.

High blood pressure is often referred to as a silent killer because in the early stage of the disease, there are no symptoms. The person will not know that he or she has the disease. The only way to detect the disease is by measuring the blood pressure. In the past, systolic pressure of $140 \mathrm{mmHg}$ and a diastolic pressure of $90 \mathrm{mmHg}$ or less were regarded as normal (Akabue, 2000). However recently the world health organization and the international Hypertension society (WHO-IHS) adopted the values of blood pressure of $120 / 80 \mathrm{mmHg}$ as optimal and normal BP is classed as less than $135 / 85 \mathrm{mmHg}$.

When high blood pressure remains, untreated for a long time or is poorly controlled, it will have damaging effects on the important organs in the body viz, the heart, brain, kidneys and eyes. The goal of managing hypertension is to normalize the blood pressure and not just reduce it (Nwadioghoha 2011) hence the research study on this plant walnut. 


\section{Medicinal Value And Content Of Walnut:}

Compared to certain other nuts, such as almonds, peanuts and hazelnuts, walnuts (especially in their raw form) contain the highest total level of antioxidants, including both free antioxidants and antioxidants bound (Retrieved doc, 2011).

Feeding trial has shown cholesterol -lowering trends in walnut-enriched diets compared with control diets (Feldman, 2002). Clinical trials suggest reduction in cardiovascular disease (CVD) risk and mortality associated with increased nut consumption. The nut has effects on CVD risk factors such as Lipid profiles vascular inflammation and blood pressure after various interventions that have included nuts.

\section{Subjects:}

\section{Materials And Methods:}

The subjects consist of Middle age (Men and Women) and old age (Men and Women) who were diagnosed with the aid of blood pressure apparatus to be hypertensive. The control subjects were apparently healthy subjects consisting both middle age and old age who had normal blood pressures. The average weight of the subjects (control and test was in the range of $65-85 \mathrm{~kg}$ body weight.

\section{Preparation Of Walnut Fruits:}

To remove the husk from kernel can lead to hand staining. Walnut hulls contain phenolics that stain hands and can cause skin irritation (Cosmulescu et al, 2010). Mature walnut fruits were selected and boiled with hot water till they cook very well to avoid staining hands. They were given to the control and test subjects to eat eight (8) nuts everyday for 2 days.

\section{Toxicity Studies:}

The $\mathrm{LD}_{50}$ of the extract of walnut in mice was determined using Lorke's method (1983). Mice (60-80g) were fasted overweight for 22 hours and doses of the extract of walnut $(10 \mathrm{mg})$ was administered intraperitoneally to the groups of the mice $(\mathrm{n}=3)$ and observed for $24-48$ hours. When no death occurred, subsequent doses $(15 \mathrm{mg} / \mathrm{kg}, 29 \mathrm{mg} / \mathrm{kg}$ body weight) were administered to fresh groups of mice $(\mathrm{n}=3)$ and observed for another 24-48 hours. The mice that served as control received normal saline only. The $\mathrm{LD}_{50}$ for the extract was calculated by geometric mean of the dose killing none of the three mice in the group and dose killing all the animals in the group.

$$
\mathrm{LD}_{50}=\sqrt{\begin{array}{c}
\text { Dose killing all animals in the group X Dose killing none of the } \\
\text { animals in the group. }
\end{array}}
$$

\section{Phytochemical Analysis Of Leaves:}

The aqueous extract of the walnut fruit was screened for the presence or absence of metabolites using standard phytochemical screening procedures as described by Harbourne (1973), Trease and Evans (1996). The extract was tested for saponins, alkaloids, flavenoids, resins, calcium, reducing sugars, glycosides, carbohydrates, steroids, acidic compounds, fats and oils.

\section{Experimental Design:}

130 subjects were grouped in four groups in this study. The apparently healthy subjects were males (Group A; 9 persons,) and females (Group B, 9 persons) were used as controls while the male hypertensive subjects was designated as the male Group C (9 persons) and the female Group D (9 persons). They were administered with eight (8) walnut fruits daily for three (3) days. Their blood pressure, haematological and biochemical profile were analyzed pre and post administration of walnut fruit.

\section{Determination Of Haematological Biochemical Profiles:}

Blood samples were collected from cubital vein of the subjects into EDTA sequesterene bottles and plain bottles for analysis within hours. The Packed cell volume and haemoglobin concentration was determined according to the haematocrit method described by Alexander and Griffiths (1993), white blood cell count and platelet count were estimated according to the visual method of Dacie and Lewis (1991).

The biochemical analysis was carried out as described by Baker (1985) while the blood pressures of subjects were measured with use of sphynomanometer and cuff.

\section{Statistical Analysis:}

The results obtained in the study for $\mathrm{Hb}$ concentration, platelet and WBC count, serum electrolyte, urea and creatinin, packed cell volume were represented as mean and Standard deviation (Mean \pm S.D) while 
students' T- test was used to compare the result of the control and the test. A $\mathrm{P}$-value of less than $(\mathrm{P}<0.05)$ or equivalent to $(\mathrm{P}=0.05)$ was considered statistically significant.

\section{Results}

The results obtained in the study are shown in Tables (1-3) and figure.

Table 1: Phytochemical study of walnut (Juglan nigra)

\begin{tabular}{|c|c|c|c|c|c|c|c|c|}
\hline & $\begin{array}{l}\text { Alkaloi } \\
\text { ds }\end{array}$ & $\begin{array}{l}\text { Glycosid } \\
\text { es }\end{array}$ & $\begin{array}{l}\text { Flavenoid } \\
\mathrm{s}\end{array}$ & $\begin{array}{l}\text { Carbohydrate } \\
\mathrm{S}\end{array}$ & $\begin{array}{l}\text { Calciu } \\
\mathrm{m}\end{array}$ & $\begin{array}{l}\text { Reducin } \\
\text { g sugar }\end{array}$ & $\begin{array}{l}\text { Saponi } \\
\mathrm{n}\end{array}$ & $\begin{array}{l}\text { Resin, } \\
\text { Tanins, } \\
\text { Steroids, } \\
\text { Terpenoi } \\
\text { ds. }\end{array}$ \\
\hline $\begin{array}{l}\text { Degree of } \\
\text { concentrati } \\
\text { on }\end{array}$ & - & + & - & +++ & ++ & + & - & - \\
\hline
\end{tabular}

\footnotetext{
- Negative

$+\quad$ Present in small concentrations.

$+\quad$ Present in moderate concentrations

$++\quad$ Present in high concentrations.
}

TABLE 2: $\quad$ Haematological profile of subjects after 28 days walnut consumption.

\begin{tabular}{|c|c|c|c|c|}
\hline GROUPS & $\mathrm{HB} \mathrm{g} / 100 \mathrm{ml} \pm \mathrm{S} . \mathrm{D}$ & $\mathrm{PCV} \mathrm{m^{3 }} \pm \mathrm{S} . \mathrm{D}$ & WBC per $\mathrm{mm}^{3} \pm$ S.D & $\begin{array}{l}\text { Platelet count } \times 10 \\
9 / 1 \pm \text { S.D }\end{array}$ \\
\hline Control subjects male $=20$ & $15.0 \pm 0.6$ & $45.0 \pm 1.8$ & $5,170 \pm 402$ & $180 \pm 25$ \\
\hline Female $n=20$ & $14.4 \pm 0.2$ & $42 \pm 0.6$ & $5,000 \pm 370$ & $175 \pm 12$ \\
\hline \multicolumn{5}{|l|}{$\begin{array}{l}\text { Subjects after } 28 \text { days walnut } \\
\text { consumption. }\end{array}$} \\
\hline $\begin{array}{l}\text { Control male hypertensive } \\
\text { subjects } \mathrm{n}=20\end{array}$ & $15.4 \pm 0.2$ & $46.2 \pm 0.6$ & $5,208 \pm 250$ & $185 \pm 30$ \\
\hline $\begin{array}{l}\text { Test male } \\
\text { Hypertensive subjects } n=20\end{array}$ & $15.5 \pm 0.3$ & $46.5 \pm 0.9$ & $5,370 \pm 246$ & $178 \pm 24$ \\
\hline $\begin{array}{l}\begin{array}{l}\text { Control female } \\
\text { subjects } n=25\end{array} \\
\end{array}$ & $14.5 \pm 0.7$ & $43.8 \pm 2.1$ & $5,010 \pm 262$ & $180 \pm 59$ \\
\hline Test female hypertensive $\mathrm{n}=25$ & $14.8 \pm 0.9$ & $44.4 \pm 2.7$ & $5,120 \pm 130$ & $182 \pm 45$ \\
\hline P Value. & $\mathrm{P}>0.05$ & $\mathrm{P}>0 . .05$ & $\mathrm{P}>0.05$ & $\mathrm{P}>0.05$ \\
\hline
\end{tabular}

TABLE 3: $\quad$ Blood pressure and Biochemical analysis of hypertensive subjects after 28 days walnuts

\begin{tabular}{|c|c|c|c|c|c|c|c|}
\hline GROUP & $\begin{array}{l}\text { Blood } \\
\text { pressure } \\
\text { Diastolic } \\
\text { mmHg } \\
\text { S.D }\end{array}$ & $\begin{array}{l}\text { Blood pressure } \\
\text { Systolic } \mathrm{mmHg} \\
\pm \text { S.D }\end{array}$ & $\begin{array}{l}\text { Cholesterol } \\
\mathrm{mg} / \mathrm{dl} \pm \mathrm{S} . \mathrm{D}\end{array}$ & $\begin{array}{l}\mathrm{Na}^{+} \text {iu/L } \pm \\
\text { S.D }\end{array}$ & $\begin{array}{l}\mathrm{K}^{+} \text {iu/L } \pm \\
\text { S.D }\end{array}$ & $\begin{array}{l}\mathrm{CL}^{-} \mathrm{iu} / \mathrm{L} \pm \\
\text { S.D }\end{array}$ & $\begin{array}{l}\mathrm{HCO}_{3}^{-} \text {iu/L } \\
\pm \text { S.D }\end{array}$ \\
\hline $\begin{array}{l}\text { Control subjects Male } \\
\mathrm{n}=20\end{array}$ & $78 \pm 5.0$ & $105 \pm 1.5$ & $168 \pm 2.4$ & $138 \pm 0.3$ & $4.0 \pm 0.6$ & $104 \pm 0.8$ & $20 \pm 0.6$ \\
\hline Female $n=25$ & $72 \pm 3.0$ & $100 \pm 1.8$ & $166 \pm 1.5$ & $140 \pm 5.0$ & $4.1 \pm 0.4$ & $103 \pm 0.6$ & $22 \pm 0.5$ \\
\hline \multicolumn{8}{|l|}{$\begin{array}{l}\text { Subjects } 28 \text { days after } \\
\text { walnut consumption }\end{array}$} \\
\hline $\begin{array}{lr}\text { Control } & \text { male } \\
\text { hypertensive } & \text { subjects } \\
\mathrm{n}=20 & \\
\end{array}$ & $140 \pm 1.8$ & $220 \pm 1.5$ & $260 \pm 10$ & $160 \pm 18$ & $7.0 \pm 0.8$ & $158 \pm 1.7$ & $42 \pm 2.0$ \\
\hline $\begin{array}{lr}\text { Test } & \text { male } \\
\text { hypertensive } & \text { subjects } \\
\mathrm{n}=20 & \end{array}$ & $80 \pm 5.0$ & $108 \pm 0.7$ & $158 \pm 7.0$ & $141 \pm 12$ & $4.5 \pm 0.6$ & $101 \pm 2.0$ & $25 \pm 0.6$ \\
\hline $\begin{array}{lr}\text { Control } & \text { female } \\
\text { hypertensive } & \text { subjects } \\
n=25 & \\
\end{array}$ & $150 \pm 36$ & $240 \pm 2.4$ & $280 \pm 14$ & $168 \pm 12$ & $7.5 \pm 0.6$ & $161 \pm 1.8$ & $44 \pm 0.7$ \\
\hline $\begin{array}{lr}\text { Test } & \text { female } \\
\text { hypertensive } & \text { subjects } \\
n=25 & \\
\end{array}$ & $76 \pm 1.4$ & $110 \pm 0.8$ & $160 \pm 9.0$ & $139 \pm 2.0$ & $4.2 \pm 0.8$ & $100 \pm 1.5$ & $26 \pm 0.5$ \\
\hline P-value & $\mathrm{P}<0.05$ & $\mathrm{P}<0.05$ & $\mathrm{P}<0.05$ & $\mathrm{P}<0.05$ & $\mathrm{P}<0.05$ & $\mathrm{P}<0.05$ & $\mathrm{P}<0.05$ \\
\hline
\end{tabular}




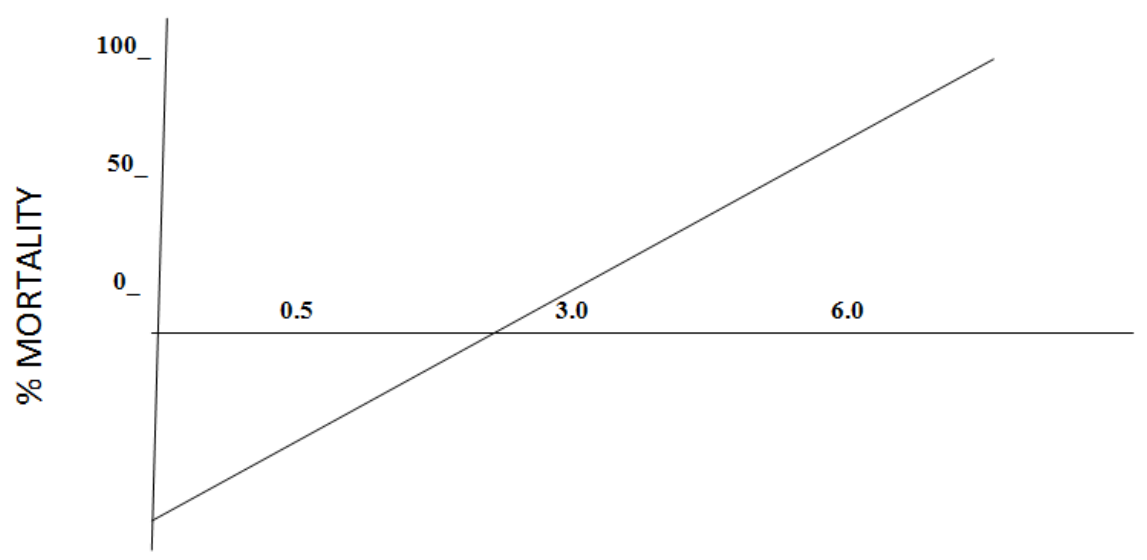

Figure 1.0: $\quad$ Mortality study showing the affect of administering graded doses $(500-6000 \mathrm{mg} / \mathrm{dl}$ i.g) in the mice of aqueous extract of walnut against the percentage mortality.

\section{Discussion}

Local medicinal herbs have been employed in the management of various diseases and their protective effect in the body from damage due to free radicals and lipids peroxidation has been reported (Wikipedia 2010). The evaluation of efficacy of Walnut (Juglan nigra) on blood pressure, haematological and biochemical profile of hypertensive subjects in Nigeria has been treated.

The haematological and biochemical analysis provides physiological information on a proper blood, and blood pressure $\mathrm{s}$ and serum electrolytes normalized after 28 days ingestion of walnut indicating that consumption of walnut indicating that consumption of walnut and meals containing walnut can help hypertension and lowering cholesterol in the body that can predispose one to cardiovascular diseases. Researchers on nut consumption and risk of cardiovascular diseases (Hu et al, 1999) discovered through feeding trials that there are cholesterol-lowering trends in walnut-enriched diets compared with control diets as revived by Feldman 2002. Many qualitative reviews have suggested beneficial effects of walnuts on cholesterol concentrations.

The macronutrients (chemical composition) and the micronutrients (Table 1) composition of walnuts confers walnuts the natural ability to improve health conditions of both male and female hypertensive subjects. Also the high levels of antioxidants found in walnuts conferred an improvement in antioxidant status as noted by decreased cholesterol level in the test hypertensive subjects (Table 3). Walnut has no effect on the haematological profile of the test hypertensive subjects.

The dividing line between normal and high blood pressure $(\mathrm{Bp})$ is arbitrary and is defined by the point above which reduction of $\mathrm{Bp}$ reduces cardiovascular risk (Solomon, 2001). The major aim of treating hypertension is to reduce the morbidity and mortality associated with it in a manner most acceptable or least convenient to the patient. This generally requires that the systolic blood pressure (SBP) be brought down below $14 \mathrm{mmHg}$ and the diastolic blood pressure (DBP) be brought below $90 \mathrm{mmHg}$.

In addition to short term walnut enriched food, there should be a modification in the life style of hypertensive subjects such as modification as reduction in table salt intake, cessation of smoking and avoidance of food with high animal fat and cholesterol content, also reduction or complete avoidance of alcohol intake has anti-hypertensive effect in the body.

\section{References}

[1]. ALEXANDER R.R and GRIFFIT J. M (1993). Haematocrit in: Basic Biochemical methods $2^{\text {nd }}$ Ed. John Willey and Sons. Inc. Publication New York Pp 186-187.

[2]. A. N., NWADIGHOGHA (2011). Stress, Health and safety Pg 16. Ephramites Printing and Publishing Company Ltd. 28/33 College road Ogui New Layout, Enugu.

[3]. BAKER F.J (1985). Biochemical analysis Introduction to Medical Laboratory Technology. Butterworths Publications Woburn London Pp 134-139.

[4]. COMMODITY PROFILE: ENGLISH WALNUTS. Ag MRC, University of California 2006.

[5]. DACIE J.K and LEWIS S.M (1991). Practical Haematology London. Churchill Living Stone Pp 186-187.

[6]. FELDMAN E (2002). The scientific evidence for a beneficial health relationship between walnuts and coronary heart disease. J Nutri 2002: 132-10628-1015 (Pubmed).

[7]. HU F.B, AT AMPFER M. J (1999). Nut consumption and risk of coronary heart disease: a review of epidemiologic evidence. Curr Artheroder Rep 1999; 1:204-9 (PubMed).

[8]. LORKE D (1983): A New approach to practical Acute Toxicity testing Arc. Toxicology 54: 275-278.

[9]. NUTRIENT DATA (Search for English Walnuts and Black Walnut)”. United States Department of Agriculture 2010. 
[10]. P. I. AKUBUE (2000): Hypertension. Textbook on Health cheeks and Health Promotion Pg 17-18. Published by Snaap Press Ltd, 1 Snaap Drive Independence Layout Enugu Nigeria.

[11]. S. COSMULESCU, I. TRANDAFR, G. ARCHIN, M. BOTU, A. BACIU, B HORT (2010): Phenolics of Green Husk in Mature Fruits. Agrobot Cluj 2010 38(1) pp 53-56 (article)

[12]. SOLOMON K (2001). Management of hypertensive with special emphasis on Nigeria. Nigeria Clinical Review pg 5-7.

[13]. The Roselle Plant, Wikipedia 2010.

[14]. TREASE G. E and EVANS W.C (1996). Textbook of Pharmacognosy, $14^{\text {th }}$ Ed, W.B Saunders, London p11.

[15]. Walnuts are top nut for healthy antioxidants American Chemical Society (Araheim), 27 March 2011, Retrieved 9 October 2011. antioxidants American Chemical Society (Araheim), 27 March 2011, Retrieved 9 October 2011. 